\title{
Metode Dakwah dalam Mengatasi Perilaku Menyimpang Remaja di Mendahara llir
}

\author{
Agus, Jamaluddin, Edy Kusnadi \\ UIN Sulthan Thaha Saifuddin Jambi \\ Email: jamaluddin@uinjambi.ac.id
}

\begin{abstract}
Abstrak: Penelitian ini dilatarbelakangi oleh fenomena yang terjadi di Kelurahan Mendahara Ilir, Kecamatan Mendahara, Kabupaten Tanjung Jabung Timur, bahwa remaja yang ada di kelurahan ini berperilaku tidak sewajarnya seperti mencuri, minuman keras, judi, narkoba dan merokok, yang membuat orang tua dan masyarakat sekitar resah. Kemudian penulis mengaitkan fenomena ini dengan metode dakwah yang dilakukan oleh da'i setempat, apakah dakwahnya telah memberi efek atau tidak. Metode penelitian yang digunakan adalah penelitian lapangan (field reseaech) kualitatif deskritif, yaitu mendeskripsikan metode dakwah dalam mengatasi perilaku menyimpang pada remaja. Hasil penelitian menunjukkan metode dakwah yang dilakukan oleh da'i adalah metode bil lisan dan menghimpun remaja dalam grup kesenian hadroh. Remaja di kelurahan Mendahara Ilir nampak mengurangi aktifitas menyimpangnya. Metode dakwah yang baik bagi remaja dapat mendorong remaja melakukan kegiatan-kegiatan positif seperti berlatih hadrah, mengajarkan hadroh kepada teman-teman yang lainnya, aktif menghadiri majelis taklim, aktif bertanya, sopan dalam berbicara, walaupun belum melibatkan semua remaja yang ada di kelurahan ini. Namun metode ini sudah bisa dikatakan cukup efektif dalam mengatasi perilaku menyimpang pada remaja.

Kata-kata kunci: metode dakwah, perilaku remaja, Mendahara Ilir.
\end{abstract}

\section{A. Pendahuluan}

Islam merupakan agama dakwah yang memuat berbagai petunjuk agar manusia secara individual menjadi manusia yang baik, beradab, dan berkualitas. Islam mengajak umatnya selalu berbuat baik sehingga mampu membangun sebuah peradaban yang maju, sebuah tatanan kehidupan yang manusiawi dalam arti kehidupan yang adil, maju, bebas dari berbagai ancaman, penindasan, dan 
berbagai kekhawatiran. ${ }^{1}$

Ketika membahas tentang moral, kita akan dihadapkan pada berbagai perilaku-perilaku manusia dalam keseharian. Melalui ilmu fikih, Islam tidak hanya mengajarkan tata-cara seputar peribadatan semesta yang menghubungkan antara seorang hamba dan Tuhannya. Islam juga memberikan pedomanpedoman etika kehidupan yang berkaitan dengan perilaku dan interaksi sosial seorang hamba sebagai wujud khalifah-Nya di muka bumi. ${ }^{2}$

Kelurahan mendahara ilir merupakan satu-satunya kelurahan yang ada di kecamatan mendahara, daerah yang berhadapan langsung dengan laut cina selatan tepatnya di kabupaten Tanjung Jabung Timur. Mayoritas penduduknya menganut agama islam. Namun, tidak semua melaksanakan syariat ajaran islam dan terutama pada remajanya.

Berdasarkan observasi penulis, di antara faktor yang mempengaruhi perilaku menyimpang pada remaja adalah kurangnya pemahaman agama dalam kehidupan sehari-hari dan mnganggap remeh pendidikan. Hal ini akan menimbulkan perilaku tidak bagus khusunya di kelurahan mendahara ilir. Penyimpangan-penyimpangan ini sangat berbahaya dan sangat rentan menimpa remaja karena mereka sedang mengalami masa pertumbuhan menuju dewasa. Apabila hal ini tidak ditangani secara serius, perilaku tersebut akan dapat menjadi momok yang menakutkan, bahkan bisa berujung pada pembangkangan.

Pada hakekatnya, kelurahan mendahara ilir merupakan kelurahan yang termasuk aktif dan sangat antusias dalam melakukan kegiatan yang bernuansa islami. Biasanya kegiatan islami, seperti Maulid Nabi, isra' mi'raj, tahun baru islam, arakan sahur dan lain sebagainya dan kegiatan ini di ikuti oleh remaja dan di ramaikan oleh anak-anak. Namun akibat kemajuan zaman, tekhnologi yang semakin tinggi yang tidak di hadapi denga baik, kegiatan-kegiatan tersebut kini hanya beberapa remaja saja yang mengikutinya. Terlihat sangat jelas di masjid-

${ }^{1}$ Moh. Ali Aziz, Ilmu Dakwah, (Jakarta: Kencana, 2004), 1.

${ }^{2}$ Abdul Halim Mahmud, Menyingkap Rahasia-Rahasia Ibadah Dalam Islam, (Jawa Barat: Keira Publishing, 2014), 1. 
masjid yang mengisi mayoritas kaum bapak-bapak dan ibu-ibu saja. Yahya menyatakan:

Pada dasarnya remaja yang berperilaku tidak sesuai dengan usianya sudah mulai tumbuh sejak usianya belum sampai ke tahap remaja, ini di buktikan dengan perilaku masyarakat di beberapa tempat yang melakukan aksi perjudian, meminum alkohol secara terang-terangan sehingga terlihat oleh anak-anak di sekitar, ini tidak mencontohkan hal-hal baik kepada anak-anak sehinnga ketika tumbuh remaja mereka mulai mencoba-coba hal seperti itu. $^{3}$

Berdasarkan hasil observasi penulis dilapangan, perilaku menyimpang remaja di kelurahan mendahara ilir, sangat terlihat jelas di buktikan dengan perjudian, narkoba, pencurian, merokok dan meminum alkohol. Apalagi kehidupan zaman sekarang bertemu dengan budaya barat yang menawarkan kebebasan, dan akhirnya perilaku remaja saat ini di Kelurahan Mendahara Ilir terlihat sangat goyah.

Masalah perilaku tidak sepantasnya yang melanda sebagian besar remaja, sangat meresahkan berbagai kalangan, termasuklah pada orang tua dan masyarakat Kelurahan Mendahara ilir. Dengan kemajuan ilmu pengetahuan dan teknologi di bidang informasi dan transformasi telah memudahkan para remaja meniru berbagai gaya hidup yang bertentangan dengan nilai-nilai Islam.

Dalam situasi ini memang tidak mudah membuat seluruh remaja Kelurahan Mendahara Ilir beprilaku seperti yang diperintahkan oleh Allah SWT dan yang telah diajarkan oleh Rasulullah SAW mengingat dari kondisi latar belakang remaja yang berbeda-beda dan pengaruh dari luar yang begitu kuat.

Untuk Mengetahui lebih lanjut mengenai aktifitas dakwah di Kelurahan Mendahara Ilir Kecamatan Mendahara Kabupaten Tanjung Jabung Timur, maka penulis tertarik untuk melakukan sebuah penelitian lebih mendalam dengan mengangkat judul "Metode Dakwah Dalam Mengatasi Perilaku Menyimpang

${ }^{3}$ Yahya, Salah Satu Da'i di Kelurahan Mendahara Ilir, Wawancara dengan Penulis, 22 Februari 2020, Keelurahan Mendahara Ilir, Rekaman Audio 
Pada Remaja di Kelurahan Mendahara Ilir Kecamatan Mendahara Kabupaten Tanjung Jabung Timur."

Berdasarkan permasalahan diatas maka rumusan masalah dari penelitian ini adalah Apa saja bentuk perilaku menyimpang pada remaja di Kelurahan Mendahara Ilir? Apa saja metode dakwah terhadap perilaku menyimpang bagi remaja di Kelurahan Mendahara Ilir? Dan Bagaimana kefektifan metode dakwah terhadap perilaku menyimpang bagi remaja di Kelurahan Mendahara lilir?

Pada penelitian ini dilakukan di Kelurahan Mendahara Ilir, dengan melibatkan instansi yang berkaitan dengan penelitian. Selain instansi penelitian ini juga melibatkan, remaja, tokoh adat, Da'i, di Kelurahan Mendahara Ilir. Kajian metode dakwah dalam mengatasi perilaku menyimpang remaja di kelurahan mendahara ilir menggunakan metode kualitatif.

\section{B. Metode Dakwah}

Dakwah adalah usaha-usaha meneyerukan dan menyampaikan kepada perorangan manusia dan seluruh umat manusia konsepsi Islam tentang pandangan dan tujuan hidup manusia di dunia ini, dan yang meliputi al-amar bi al-ma'ruf an-nahyu an al-munkar dengan berbagai macam cara dan media yang diperbolehkan akhlak dan membimbing pengalamannya dalam perikehidupan bermasyarakat dan perikehidupan bernegara. ${ }^{4}$

Dakwah menjadikan perilaku muslim dalam menjalankan Islam sebagai agama Raahmatan lil alamin yang harus didakwahan kepada seluruh manusia, yang dalam prosesnya melibatkan unsur: da'i (subjek), maaddah (materi), thoriqoh (metode), washila (media), dan mad'u (objek)dalam mencapai maqashid (tujuan) dakwah yang melekat dengan tujuan Islam yaitu mencapai kebahagian hidup di dunia dan akhirat.

${ }^{4}$ M. Natsir, Fungsi Dakwah Perjuangan Dalam Abdul Munir Mulkham Ideologis Gerakan Dakwah, (Yogyakarta: Sipres, 1996), 52. 
Dakwah juga dapat dipahami dengan proses internalisasi, transformasi, transmisi, dan difusi ajaran Islam dalam kehidupan masyarakat. Dakwah mengandung arti panggilan dari Allah Swt. Dan Rasulullah Saw. Untuk umat manusia agar percaya kepada ajaran Islam dan mewujudkan ajaran yang dipercayainya itu dalam segala segi kehidupannya. ${ }^{5}$

Metode dakwah adalah cara-cara tertentu yang dilakukan oleh seoran da'i (komunikator) kepada mad'u untuk mencapai suatu tujuan atas dasar hikmah dan kasih sayang. Hal ini mengandung arti bahwa pendekatan dakwah harus bertumpu pada suatu pandangan human oriented menempatkan penghargaan yang mulia atas diri manusia. ${ }^{6}$

\section{a. Al-Hikmah}

Kata "hikmah" dalam Al-Qur'an disebutkan sebanyak 20 kali baik dalam bentuk nakiroh maupun ma'rifat. Bentuk masdarnya adalah "bukman" yang diartikan secara makna aslinya adalah mencegah. Jika dikaitkan dengan hukum berarti mencegah dari kezaliman, dan jika di kaitkan dengan dakwah maka berarti menghindari hal-hal yang kuran relevan dalam melaksanakan tugas dakwah.

Sebagai metode dakwah, al-Hikmah diartikan bijaksana, akal budi yang mulia, dada yang lapang, hati yang bersih, dan menarik perhatian orang kepada agama atau Tuhan. Dapat dipahami bahwa al-Hikmah merupakan kemampuan dan ketetapan da'i dalam memilih dan menyelaraskan teknik dakwah dengan kondisi objektif mad'u. Al-hikmah merupakan kemampuan da'i dalam menjelaskan doktrin-doktrin Islam serta realitas yang ada dengan argumentasi logis dan bahasa yang komunikatif. Oleh karena itu, al-Hikmah sebagai sebuah sistem yang menyatukan antara kemampuan teoritis dan praktis dalam berdakwah.

${ }^{5}$ Wahidi Saputra, Pengantar Ilmu Dakwah, (Jakarta: Rajawali Pers, 2012), 2-3.

${ }^{6}$ M. Munir, Metode Dakwah, (Jakarta : Kencana, 2019), 7. 
b. Al-Mau'idza Al-Hasanah

Secara bahasa, mau'izhah hasanah terdiri dari dua kata, yaitu mau'izhah dan hasanah. Kata mau'izhah hasanah berasal dari kata wa'adza-ya'idzuwa'dzan-'idzatan yang berarti; nasihat, bimbingan, pendidikan dan peringatan, sementara hasanah merupakan kebalikan dari sayyi'ah yang artinya kebaikan

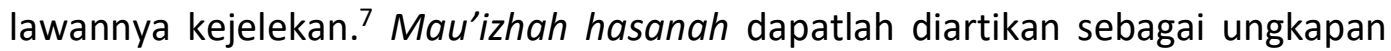
yang mengandung unsur bimbingan, pendidikan, pengajaran, kisah-kisah, berita gembira, peringatan, pesan-pesan positif (wasiyat) yang bisa dijadikann pedoman dalam kehidupan agar mendapatkan keselamatan dunia dan akhirat.

c. Al-Mujadalah Bi-al-Lati Hiya Ahsan

Dari segi etimologi (Bahasa) lafazh mujadalah terambil dari kata "jadalah" yang bermakna memintal, melilit. Apabila ditambahkan alif pada huruf jim yang mengikuti wazan Faa ala, "jaa dala" dapat bermakna berdebat, dan "mujadalah" perdebatan. Al-Mujadalah merupakan tukar pendapat yang dilakukan oleh dua pihak secara sinergis, yang tidak melahirkan permusuhan dengan tujuan agar lawan menerima pendapat yang diajukan dengan memberikan argumentasi dan bukti yang kuat. Antara satu dengan yang lainnya saling menghargai dan menghormati pendapat keduanya berperang kepada kebenaran, mengakui kebenaran pihak lain ikhlas menerima hukuman kebenaran tersebut. ${ }^{8}$

\section{Sejarah Mendahara Ilir}

Nama kelurahan mendahara ilir diambil dari nama suatu kejadian di sungai berukuran sedang yang mengatur dari arah Timur ke arah Barat, membelah kelurahan mendahara ilir menjadi dua bagian, yaitu bagian utara atau di sebut oleh masyarakat setempat hulu. Sungai ini bernama sungai tembikar. Pemukiman penduduk Kelurahan pertama kali adalah para pendatang dari pulau malaka (melayu timur) sekitar tahun 1950, tepatnya dimuara sungai tembikar

\footnotetext{
${ }^{7}$ Lois Ma'aluf, Munjid fi al-Lughah wa A'lam (Beirut: Dar Fikr, 1986), 907.

${ }^{8}$ M.Munir, Metode Dakwah, (Jakarta: Kencana, 2009), 17-19.
} 
kelompok pendatang ini kemudian diikuti dengan kelompok keluarga dari suku cina, baik yang langsung dari pulau Sulawesi, Kalimantan, Jawa, Padang, Medan, Melayu Jambi maupun suku lainnya telah berdomisili di Kelurahan Mendahara Ilir.

Maksud kedatangan penduduk kelurahan ini pertama kali adalah sebagai nelayan yang memerlukan lokasi tempat berlabuh bagi kapal yang mereka gunakan sebagai sarana menangkap ikan. Pada saat menetap ini untuk memenuhi kebutuhan hidup keluarga akan beras, kemudian mereka memulai mengolah lahan pertanian dan perkebunan. Hasilnya cukup baik dan berkembang sampai saat ini. Perkembangan penduduk kelurahan mengalami arus turun naik dari periode ke periode seperti tahun 1970 dan tahun-tahun berikutnya mengalami peningkatan sampai saat sekarang.

Sesuai perkembangan sistem administrasi pemerintahan diindonesia, sebutan desa sewaktu berdiri adalah kampong yang dikepalai oleh seseorang yang disebut dengan kepala kampung atau yang lebih populer disebut dengan panggilan datuk penghulu. Setelah diberlakukan undang-undang no 5 tahun 1979 tentang pemerintahan desa, maka pada tahun 1980 sebutan kampong berubah menjadi desa yang dikepalai oleh seseorang yang disebut dengan kepala desa, namun setelah terjadinya perubahan dari kepala desa menjadi kelurahan pada tahun 2008 sampai sekarang masih dipimpin oleh kelurahan. ${ }^{9}$ Sejak berdirinya desa sampai sekarang telah tercatat 4 orang pimpinan desa dan 3 kepala kelurahan.

\section{Perilaku Menyimpang pada Remaja}

Sebuah kenyataan ironis dibuktikan dari sebuah survei yang menggambarkan bahwa remaja pernah melakukan tindakan di luar batas nilai kesusilaan, misalnya menggunakan narkoba, berjudi, pencurian, minuman keras,

${ }^{9}$ M.Jafri, Tokoh Adat, Wawancara dengan Penulis, 23 Februari 2020, Kelurahan Mendahara Ilir, Rekaman Audio. 
dan merokok. Begitupun remaja yang masih sekolah selalu mendapat banyak hambatan atau masalah yang biasanya muncul dalam bentuk perilaku menyimpang. Berikut bentuk perilaku menyimpang pada remaja di kelurahan mendahara ilir.

\section{Penyalagunaan Narkoba}

Penyalahgunaan narkoba adalah salah satu prilaku menyimpang yang banyak terjadi dalam masyarakat saat ini. Bentuk-bentuk penyalahgunaan narkoba, seperti mengkonsumsi dengan dosis yang berlebihan, memperjualbelikan tanpa izin serta melanggar aturan yang ditetapkan dalam UndangUndang Nomor 35 Tahun 2009, tentang Narkotika.

Penyalahgunaan narkoba dikalangan remaja merupakan tindakan yang tidak sesuai dengan norma dan nilai sosial yang berlaku dalam masyarakat dinamakan perilaku menyimpang. Penyimpangan terjadi apabila seseorang atau sekelompok orang tidak mematuhi norma atau patokan dan nilai yang sudah baku di masyarakat. ${ }^{10}$

Berdasarkan hasil observasi penulis di Kelurahan Mendahara llir yang menjadi penyebab remaja menyalah gunakan narkoba yaitu adanya faktor dari individu dalam hal ini diri sendiri, faktor lingkungan dalam hal ini pengaruh dari teman sebaya, teman sepergaulan dan faktor ketersediaan yang membuat mereka menyalahgunakan narkoba.

Narkoba bukan benda asing lagi bagi telinga remaja, dari bangku sekolah dasar mereka sudah di kenalkan dengan benda yang membuat orang kecanduan apabila menggunakannya. Bagi remaja Kelurahan Medahara llir, yang putus sekolah dan sudah memiliki pekerjaan, mendapatkan barang ini sangatlah mudah, dengan harga sekitar lima puluh ribuan hingga dua ratus ribuan mereka bisa membeli barang ini . mengapa sangat mudah, ini di karenakan akses masuk ke tempat ini sangat mudah, kondisi lokasi Kelurahan Mendahara Ilir yang

10 Jimmy Simangunsong, "Penyalagunaan Narkoba Di Kalangan Remaja", EJurnal,(2015), 13. 
berhadapan langsung dengan laut cina selatan, dimana tempat kapal-kapal sering singgah ke dermaga untuk membeli perlengkapan kapal, sehingga dari sini lah mulai muncul penyebaran narkoba. Adapun jenis narkoba yang di gunakan remaja, Yuriko menyatakan "Ada beberapa jenis narkoba yang sering digunakan oleh remaja dan tertangkap pihak kepolisian kelurahan mendahara ilir diantaranya adalah ganja, sabu-sabu, dan lem aibon". ${ }^{11}$

Judi

Judi secara harfiah berarti memperoleh sesuatu dengan cara yang mudah, memperoleh suatu keuntungan tanpa bekerja. Judi atau permainan "judi" atau "perjudian" menurut Kamus Besar Bahasa Indonesia adalah "Permainan dengan memakai uang sebagai taruhan". Berjudi ialah "Mempertaruhkan sejumlah uang atau harta dalam permainan tebakan berdasarkan kebetulan, dengan tujuan mendapatkan sejumlah uang atau harta yang lebih besar dari pada jumlah uang atau harta semula". ${ }^{12}$ Perjudian merupakan salah satu permainan tertua di dunia hampir setiap negara mengenalnya sebagai sebuah permainan untung-untungan. Judi juga merupakan sebuah permasalahan sosial dikarenakan dampak yang ditimbulkan amat negatif bagi kepentingan nasional teruama bagi generasi muda karena menyebabkan para pemuda cenderung malas dalam bekerja dan dana yang mengalir dalam permainan ini cukup besar sehingga dana yang semula dapat digunakan untuk pembangunan malah mengalir untuk permainan judi, judi juga bertentangan dengan agama, moral dan kesusialaan. Permainan judi juga dapat menimbulkan ketergantungan dan menimbulkan kerugian dari segi meteril dan imateril tidak saja bagi para pemain tetapi juga keluarga mereka.

Berdasarkan observasi penulis jenis judi yang sering digunakan remaja di kelurahan mendahara ilir adalah permainan kartu dan sabung ayam.Permainan

\footnotetext{
11 Yuriko, Kanit Pembinaan Masyarakat Polsek Kelurahan Mendahara Ilir, Wawancara dengan Penulis,23 Februari 2020, Kelurahan Mendahara Ilir, Rekaman Audio.

${ }^{12}$ Poerwadarminta, Kamus Besar Bahasa Indonesia, Edisi Kedua,(Jakarta: Balai Pustaka, 1995), 419.
} 
ini menjadi favorit bagi para remaja apa lagi jika menghasilkan uang. Hal ini sudah menjadi kebiasaan mereka bahkan tidak ragu untuk memainkannya di tengah-tengah pemukiman masyarakat.

Bagi masyarakat sekitar permainan judi sudah menjadi hal yang lumrah, permainan judi kartu ini biasa dilakukan ketika begadang pada saat acara 1 malam sebelum resepsi pernikahan dan dilakukan lebih dominan kaum bapakbapak, namun seiring berjalannya waktu permainan ini malah sering dimainkan tidak hanya pada saat ada acara pernikahan saja. Hal yang paling memprihatinkan adalah permainan judi ini dilakukan secara terang-terangan sehingga terlihat oleh anak-anak dan remaja sekitar, maka dari sinilah mulai timbul permasalahan yang mengakibatkan banyaknya remaja di Kelurahan Mendahara Ilir sampai saat ini masih bermain judi kartu.

Tidak hanya judi kartu, judi sabung ayam juga menjadi hal yang sudah biasa, pemainnya mulai dari anak-anak, remaja, dewasa, dan orang tua. Sebelum maraknya judi sabung ayam di tempat terbuka, biasanya mereka menggunakan tempat yang tersembunyi, seperti di kebun kelapa dan pinang, namun sekarang tempat untuk permainan ini sudah dilakukan dimana saja, dengan catatan ada ditanah lapang yang bisa menarik penonton dan ring sabung ayam. Abdul mutalib menyatakan :

Kini tidak bisa di pungkiri lagi, kalau kita lihat dengan mata kita sendiri sangat terlihat jelas setiap sorenya anak-anak dan remaja menggendong ayamnya untuk di bawa ke tempat perjudian sabung ayam, hal ini sangat merusak moral dan agama. Maka dari itu peran orang tua sangat penting di sini. ${ }^{13}$

\section{Pencurian}

Secara etimologis pencurian berasal dari kata sariqah, yang berarti melakukan sesuatu terhadap orang lain secara sembunyi. Secara terminologis

${ }^{13}$ Abdul mutalib, Kelompok Penyuluh Agama Islam Mendahara, Wawancara dengan Penulis, 20 Februari 2020. Kelurahan Mendahara Ilir, Rekaman Audio. 
pencurian yaitu mengambil harta milik orang lain dengan cara diam-diam, yaitu dengan jalan sembunyi-sembunyi. Pencurian mengandung tiga unsur, yaitu :

a. Mengambil milik orang lain

b. Mengambilnya secara sembunyi-sembunyi

c. Milik orang lain itu ada di tempat penyimpanan. ${ }^{14}$

Perilaku pencurian menjadi salah satu perilaku menyimpang yang bisa mengakibatkan kerugian bagi korban. Selain meresahkan masyarakat pelaku pencurian juga bisa mengancam nayawa orang. Pencurian yang dilakukan oleh remaja di kelurahan Mendahara ilir rata-ratanya disebabkan oleh faktor ekonomi, kecanduan merokok, narkoba dan minum-minuman keras, karena orangtua hanya memberikan uang yang pas-pasan bagi mereka, sehingga untuk mendapatkan uang mereka mengambill jalan pintas dengan mencuri. Muhammad Nuur menyatakan :

Beberapa kasus pencurian telah di laporkan ke pihak kepolisian di kelurahan mendahara ilir, jika kasus pencuriannya berat kita tindak lanjuti namun apabila kasusnya ringan kita menyelesaikannya dengan cara kekeluargaan. ${ }^{15}$

Kasus pencurian yang dilakukan oleh remaja di kelurahan mendahara ilir sangat beragam, mulai dari pencurian barang seperti handphone, rokok, snack dan uang.

\section{Minuman Keras}

Dari sudut pandang seorang remaja yang sehat, minuman keras mungkin dilihat sebagai sebuah ritual akil balig yang esensial, pemberontakan melawan pembatasan-pembatasan orang dewasa dengan berpartisipasi dalam hobi populer orang dewasa. Mencari kesenangan, rasa percaya diri dan identitas tampak lebih dapat dicapai dan lebih menyenangkan ketika terintoksikasi. Bagi banyak orang, intoksikasi menciptakan peluang untuk membentuk hubungan

${ }^{14}$ Mardani, Hukum Pidana Islam, (Jakarta: Prenada Media Grop, 2019), 63-64.

${ }^{15}$ Muhammad Nuur, Kanit Intelkom Polsek Mendahara, Wawancara dengan Penulis, 23 Februari 2020, Kelurahan Mendahara Ilir, Rekaman Audio. 
mengambil risiko atau menghindari kepedihan kesadaran tentang diri sendiri, kesepian, atau kesedihan. Kebanyakan masyarakat berat dengan bangga mempromosikan konsumsi alkohol sebagai bagian dari kehidupan orang dewasa, sehingga remaja yang bercita-cita untuk bergabung dengan golongan dewasa cenderung percaya bahwa sangat penting bagi mereka untuk minum alkohol. ${ }^{16}$ penyebab penyalahgunaan minuman memabukkan dan sejenisnya adalah :

a. sebab dalam diri individu

Seorang individu yang minum minuman keras yang mengandung alkohol, terdorong oleh berbagai motivasi. Motivasi tersebut adalah ajakan teman, keingintahuan, melupakan sejenak masalah. Adanya tarikan individu untuk menjadi konsumen tetap dari minuman keras yang didorong oleh berbagai motivasi yang kuat, konsekuensinya yang logis ialah munculnya para penjual atau penawaran dari produsen. Maka terdapat pula sebab yang timbul dari dalam masyarakat sendiri.

b. Sebab dari masyarakat yang mensuplai.

Seperti telah dikemukakan di dalam masyarakat yang menyadari akan adanya permintaan alkohol timbul beberapa kelompok orang yang melakukan pengadaan alkohol untuk tujuan tertentu.

1.) Untuk kepentingan dagang atau ekonomi, atau untuk mengeruk banyak uang.

2.) Untuk tujuan politik, yaitu memperlemah individu dalam masyarakat. ${ }^{17}$

Berdasarkan hasil wawancara penulis dengan para informan, rata-rata mereka mengkomsumsi minuman keras karena pergaulan, ajakan teman, Ruslan menyatakan:

Saya mengkonsumsi minuman beralkohol karena rasa ingin tahu dan mencoba-coba, menghilangkan permasalahan, menghilangkan rasa sedih mengatasi stres, menyesuaikan diri dengan teman dan menahan rasa

\footnotetext{
${ }^{16}$ Kathryn Geldard,Konseling Remaja, (Yogyakarta: Pelajar, 2012),217.

17 Soedjono Dirdjosisworo, Alkoholisme Paparan Hukum dan Kriminologi, (Bandung Remadja Karya, 1984), 138-139.
} 
marah. Pertama kali saya minum-minuman beralkohol pada saat saya masih duduk di bangku Sekolah Menengah Pertama hingga sekarang. ${ }^{18}$

\section{Merokok}

Bagi remaja di kelurahan mendahara ilir merokok merupakan sesuatu yang sangat lumrah, merokok merupakan perilaku simbolisasi. Simbol dari kematangan, kekuatan, kepemimpinan, dan daya tarik terhadap lawan jenis.

Perilaku merokok pada remaja sebagai identitas sosial dalam pergaulan terbentuk karena adanya respon mengenai lingkungan berupa fisik serta perilaku masyarakat di sekitar mereka. Masyarakat di sekitar remaja perokok, khususnya laki-laki, sebagian besar merokok. Setiap hari remaja perokok menyaksikan masyarakat merokok secara ekslusif. Sebagian besar, individu yang usianya di atasnya, dalam keseharian dalam melakukan komunikasi dengan informan selalu merokok. Hal tersebut terjadi semenjak remaja perokok masih kecil. Juga di lingkungan internal keluarga remaja perokok, ayah, atau kakek (semua yang bergender laki-laki) selalu merokok di rumah ketika ada remaja.

Secara langsung, masyarakat di lingkungan informan menyuruh untuk merokok sebagai bentuk maskulinitas. Tidak merokok berarti tidak laki-laki. Dengan kondisi lingkungan yang ada di sekitar informan, seolah perkataan tersebut memang benar. Bahwa ketika laki-laki tidak merokok maka tidak bisa disebut laki-laki. Selain itu, merokok juga disebut sebagai media untuk meningkatkan pamor seorang laki-laki. Istilah keren atau gaul sebagai andalannya. Ketika merokok, laki-laki merasa percaya diri. Hal tersebut dipercaya oleh informan.

Sejak awal informan sudah tidak menganggap bahwa merokok adalah perilaku yang salah. Lantaran terjadi kebiasaan di lingkungannya, merokok menjadi hal yang wajar. Hal tersebut menjadian informan terpancing untuk mencoba merokok. Dari hal tersebut, remaja perokok kemudian memaknai

${ }^{18}$ Ruslan, Informan Remaja Pengguna Minuman Keras, Wawancara dengan Penulis, 2 April 2020, Kelurahan Medahara Ilir, Rekaman Audio. 
bahwa merokok adalah hal yang lumrah bagi seorang laki-laki. Bukan menjadi perkara tabu atau aneh, melainkan menjadi sebuah kebiasaan atau kewajaran. ${ }^{19}$

Maraknya penjualan rokok di kelurahan mendahara ilir serta lingkungan yang mayoritas penduduknya adalah perokok membuat remaja di kelurahan mendahara ilir tidak segan lagi untuk merokok di depan khayalak ramai padahal mereka masih berstatus sebagai pelajar SMP dan SMA, Reza Gunawan menyatakan :

Awalnya saya hanya mecoba-coba 1 batang rokok, itupun saya terabatukbatuk. Waktu itu saya masih duduk di bangku sekolah kelas 1 SMP. Awal saya mencoba rokok itu karena melihat teman-teman saya semuanya merokok, sehingga saya terpengaruh dan akhirnya seiring berjalannya waktu saya kecanduan, hingga saat ini saya masih merokok dan perharinya itu saya bisa menghabiskan 1 bungkus rokok.$^{20}$

\section{Faktor Yang Mempengaruhi Perilaku Menyimpang Pada Remaja}

Untuk mengetahui faktor yang menyebabkan remaja melakukan perilaku menyimpang, ada dua faktor yaitu: Faktor internal, Kontrol diri yang lemah terjadi karena kenakalan remaja dapat digambarkan sebagai bentuk kegagalan mengembangkan kontrol diri dalam tingkah laku remaja. Beberapa anak dalam mengembangkan kontrol diri yang seharusnya sudah diterima ketika mengalami proses pertumbuhan. ${ }^{21}$ Oleh karena itu kontrol diri yang lemah menjadi pengaruh remaja melakukan perilaku menyimpang. Menurut Kartono anak-anak remaja yang melakukan kejahatan atau melakukan perilaku menyimpang pada umumnya kurang memiliki kontrol diri tersebut dan suka menegakkan standar tingkah laku sendiri disamping meremehkan keberadaan orang lain. ${ }^{22}$

Keyakinan agama mempengaruhi perilaku manusia, bukan hanya secara individual, tetapi juga sosial. Penghayatan para remaja terhadap ajaran agama dan tindak keagamaan yang tampak terhadap perilaku para remaja banyak

\footnotetext{
${ }^{19}$ Rizky Septi Nugroho, "Perilaku Merokok Remaja”, Jurnal (2010), 16

${ }^{20}$ Reza Gunawan, Informan Remaja Pengguna Rokok, Wawancara dengan Penulis, 2 April 2020, Kelurahan Mendahara Ilir, Rekaman Audio.

${ }^{21}$ John W. Santrock Adolescence, Diterjemahkan oleh Widyasinta dan Indra Sallama,(Jakarta : Erlangga,2002), 258.

${ }^{22}$ Kartini Karton, Kenakalan Remaja, (Jakarta : Raja Grafindo Persada. 2014), 9.
} 
berkaitan dengan faktor perkembangan remaja. ${ }^{23}$ Lingkungan keagamaan, baik dari lembaga-lembaga pendidikan keagamaan, tempat-tempat peribadatan, maupun kegiatan-kegiatan keagamaan adalah sangat penting dalam pembentukan jiwa remaja. Kegiatan-kegiatan keagamaan misalnya sekolah atau permainan yang terletak dekat mesjid atau rumah ibadah lainnya, akan memberikan pengalaman tertentu bagi anak-anak atau remaja yang bersekolah atau bermain ditempat itu,Reja Pajarismanda menyatakan:

[S]aya terlahir dari keluarga saya muslim 100\% tapi saya mengakui bahwa kami kurang mentaati syariat agama islam. Dari kecil saya diajarkan mengaji namun setelah tamat sekolah dasar saya berhenti mengaji, setelah berada di sekolah menengah atas saya juga tinggal kelas dan tidak melanjuti sekolah. Padahal dari sekolah saya bisa belajar agama lebih baik. Saya juga jarang ke masjid untuk shalat berjamaah dan ikut kegiatan majelis taklim, mungkin biasdihitung dengan jari. Mungkin akibat dari kurangnya pemahamantentang agama saya nekat melakukan apa saja yang membuat saya senang seperti meminum minuman keras. ${ }^{24}$

Pengalaman yang didapatnya melalui penglihatan dan pendengaran tentang rumah ibadah dan kegiatan-kegiatan keagamaan yang dilakukan, akan merupakan unsur positif bagi pembinaan kepribadiannya. Hatinya akan dekat dengan agama dan dengan sendirinya sikap terhadap agama tersebut akan menjadi positif. Pengaruh keagamaan itu akan lebih besar apabila remaja ikut aktif dalam kegiatan sosial keagamaan, terutama bagi mareka yang mengalami kegoncangan dan ketidaktenangan dalam ke luarga. Apabila remaja tidak meyakini suatu agama tidak mendapatkan pendidikan dan pengalaman keagamaan sejak kecil, maka ia akan bingung dalam menghadapi kesukaran pribadinya. Mereka yang kosong dari pengalaman keagamaan itu akan mudah tersebut kepada kegiatan - kegiatan yang menyimpang.

Faktor Eksternal, Faktor lain yang mempengaruhi perkembangan dan perilaku reamaja ialah faktor keutuhan keluarga, yang dimaksud dengan faktor

${ }^{23}$ Jalaluddin, Psikologi Agama,(Jakarta : Raja Grafindo Persada, 2003), 74

${ }^{24}$ Reza Pajarismanda, Remaja Berperilaku Menyimpang, Wawancara dengan Penulis, 8 April 2020, Kelurahan Mendahara Ilir, Rekaman Audio. 
keutuhan keluarga ialah keutuhan dalam struktur keluarga, yaitu di dalam keluarga itu ada ayah, ibu dan ana-anak. Apabila tidak ada ayah atau ibu keduanya tidak ada, maka struktur keluarga itu tidak utuh lagi. Apabila ayah atau ibunya jarang pulang kerumah atau berbulan-bulan meninggalkan rumah, karena tugas-tugas lai, maka struktur keluarga itu pun sebenarnya tidak utuh lagi. Begitu pula apabila orang tuanya bercerai, maka keluarga itu pun tidak utuh lagi. ${ }^{25}$

Keadaan sosial ekonimi keluarga dapat juga berperan terhada perkembangan anak-anak. Misalnya anak yang orang tuanya berpenghasilan cukup (sosial ekonominya cukup), maka anak-anak tersebut lebih banyak mendapat kesempatan untuk mengembangkan berbagai macam-macam kecakapan. Begitu pula sebaliknya bagi anak yang orang tuanya sosial ekonominya kurang akan mempengaruhi perkembangan rmaja dan bisa melakukan perbuatan-perbuatan yang tidak diinginkan seperti perilaku menyimpang yang akan merugikan remaja yang bersangkutan. ${ }^{26}$

Perkembangan remaja sangat di pengaruhi oleh lingkungan tempat tinggalnya, misalnya remaja berteman dengan orang yang nakal maka dia akan ikut nakal juga begitu juga sebaliknya. Karena remaja masih sangat rentan terhadap perilaku yang ada di tempat tinggalnya. Lingkungan masyarakat merupakan kondisi tempat tinggal yang turut mempengaruhi pola pikir dan berkembangnya jiwa remaja. Bentuk salah satu manifestasi dan penentangan terhadap lingkungan adalah geng remaja. Saat ini geng remaja telah menjurus pada hal-hal yang negatif, seperti perkelahian masal, minum-minuman keras (alkohol). Narkoba, melakukan kejahatan seksual dan perampokan. ${ }^{27}$

Lingkungan sosial yang dimaksud adalah teman sebaya. Teman sebaya merupakan lingkungan bergaul seorang anak dan melalui interaksi dengan teman sebaya, individu akan berkenalan dan mulai bergaul dengan teman-teman dengan pola perilaku yang berbeda-beda. Sehingga melalui interaksi inilah

\footnotetext{
${ }^{25}$ Abu Ahmadi, Psikologi Sosial, (Jakarta : Rineka Cipta, 2007), 239.

${ }^{26}$ Ibid, 236.

${ }^{27}$ Sofyan Wilis, Remaja dan Masalahnya, (Bandung : Alfabeta, 2012),66.
} 
masing-masing individu akan saling memahami keinginan-keinginan dan tidak jarang individu akan membentuk kelompok-kelompok. Jika perilaku temanteman sebayanya telah dirasa cocok, pergaulan teman sebaya dapat mempengaruhi perilaku remaja. Perilaku tersebut bisa berupa perilaku positif dan dapat pula berupa perilaku negatif. ${ }^{28} \mathrm{Abdul}$ Muthalib menyatakan :

Sebenarnya banyak faktor yang menyebabkan rusaknya karakter remaja, salah satu hal yang paling besar adalah faktor keluarga, dapat dipastikan bahwa remaja tidak mendapatkan tempat yang baik pada rumahnya, apa yang menjadi keinginannya tidak terakomodir oleh orang tuanya atau memang terjadi faktor external di luar dirinya yakni bisa saja broken home, sehingga mereka lari kepada sesuatu yang sesungguhya tidak baik. Maka dari itu hal ini sangat diperlukannya peran orang tua, masyarakat dan da'i, bersama-sama untuk meminimalisir perilaku menyimpang pada remaja di Kelurahan Mendahara llir ${ }^{29}$

\section{E. Dakwah dalam Kehidupan Remaja}

Pada dasarnya remaja-remaja yang ada di Kelurahan Mendahara llir ini memang sering melakukan perilaku-perilaku penyimpangan dari perilaku penyimpangan ringan maupun yang berat, hal ini terjadi karena Sumber Daya Manusia yang semakin meningkat di Kelurahan ini dan juga faktor Teknologi dan informasi yang semakin canggih sehingga perilaku menyimpang pada remaja di kelurahan mendahara ilir ini lebih meningkat.

Pertambahan penduduk yang terus meningkat dan pergeseran budaya yang terjadi di kelurahan ini hampir hilang, hal ini tercermin dari tingkah laku menyimpang pada remaja, bisa dikatakan sikap invidualis sudah terjadi di kelurahan ini. Apa lagi teknologi zaman sekarang semakin canggih dan sangat mudah di akses .

Orangtua salah satu faktor penting terjadinya perilaku menyimpang di kalangan remaja. Kalau orang tua mendidik dan memperhatikan anaknya dengan 2002), 22.

${ }^{28}$ Mu'tadin, Pengantar Pendidikan dan Perilaku Kesehatan, (Yogyakarta : Andi Offset,

29 Abdul Thalib, Kelompok Penyuluh Agama Islam Mendahara, Wawancara dengan Penulis, 20 Februari 2020, Kelurahan Mendahara Ilir, Rekaman Audio. 
baik, maka anaknya akan menjadi baik. Karena kebanyakan orangtua sudah sibuk dengan urusan masing-masing sampai-sampai kepentingan anaknya terabaikan. Hal itu yang membuat anak-anak remaja melakukan hal-hal yang tidak pantas, karena kurangya didikan dan perhatian dari orangtua mereka, Yoga Pratama menyatakan:

Saya merupakan anak pertama dari dua bersaudara, di rumah saya merasa diasingkan orang tua saya tidak perduli dengan saya, adik saya terkena penyakit autis daris sejak lahir, orang tua saya lebih memperhatikan adik saya, ayah saya selalu bekerja tiap hari, pergi pagi pulang malam, ayah saya seorang nelayan dan saya bertemu ayah saya ketika malam saja. Karena jarang mendapat perhatian saya bebas keluar kesana kemari pulang malam dan tidak pernah kena tegur. ${ }^{30}$

Sama hal nya seperti remaja pada umumnya yang ada didaerah lain, remaja di kelurahan mendahar ilir juga bersekolah, hanya saja lingkungan mereka yang berbeda. Maka selain faktor orangtua, masyarakat dan lingkungan sekitarpun menjadi penyebab perilaku menyimpang pada remaja. Lingkungan yang penuh dengan peredaran minuman beralkohol, perjudian pernikahan, merokok dihadapan anak-anak dan perilaku menyimpang lainnya. Sangat di sayangkan sekali orangtua yang seharusnya menjadi contoh bagi anak-anak tetapi sangat berbeda fakta yang terjadi di kelurahan mendahara ilir.

Ada beberapa tempat dimana lingkungan yang memang tidak mendukung serta remaja nya yang berperilaku menyimpang, khususnya di kelurahan mendahara ilir ini dapat di petakan. tempat dimana kelompok-kelompok remaja yang berperilaku menyimpang dan di situ lah terlihat lingkungannya yang memang sedikit tidak agamis.

Tuntutan zaman yang mendominasi remaja sangat dominant. Oleh karenanya, materi yang disusun juga harus merupakan jawaban zaman. Materi yang dipersiapkan hendaknya mudah dicerna, remaja mempunyai bahasa sendiri dalam bahasa sehari-hari, bahkan kadangkala punya ambisi menggunakan

\footnotetext{
${ }^{30}$ Yoga Pratama, Remaja Kurang Perhtian Orang Tua, Wawancara dengan Penulis, 6 April 2020, Kelurahan Mendahara Ilir, Rekaman Audio.
} 
bahasa popular walaupun mereka sendiri kurang memahami cara penjabarannya baik pada remaja yang masih sekolah maupun yang putus sekolah. cocok untuk kelompok remaja yang berbeda. Untuk itu pemilihan materi haruslah tepat, apakah itu untuk remaja pelajar (siswa dan mahasiswa), apakah itu remaja yang berlatar belakang ekonomi lemah, juga apakah pendengar itu heterogen, artinya berbagai tingkat dan mutu pengetahuannya ataukah sejenis. Dengan beraneka latar belakang kehidupan remaja, akan lebih memacu seorang da'i untuk memiliki keterampilan menyusun materi.

Terdapat berbagai kenyataan yang dilakukan oleh para muballigh. Ternyata meteri dakwah selalu hanya bersifat pengulangan terhadap apa yang telah dikemukakan terdahulu. Pengembangan materi terasa sangat sulit dilakukan oleh sebagian para subyek dakwah. Pada hal remaja pada umumnya menyenangi hal-hal yang baru dan cepat bosan bagi hal yang telah atau sering didengarnya. Karena itu da'i harus berusaha memberikan suatu hal yang baru dalam materi dakwahnya walaupun bersifat pemantapan.

Satu hal yang perlu diperhatikan adalah daya kritis remaja terhadap hal-hal yang tidakmasuk akal, tidak logis. Oleh karena itu, materi dakwah harus logis. Dengan kata lain, mengajarkan agama kepada remaja hendaklah disesuaikan dengan kondisi jiwa dan lingkungan hidupnya. ${ }^{31}$

Materi yang diperlukan untuk suatu kelompok masyarakat belum tentu cocok untuk kelompok masyarakat yang berbeda. Oleh sebab itu pemilihan materi haruslah tepat, apakah itu untuk kaum muda, pelajar, mahasiswa, petani, pekerja kasar, pengusaha, pegawai, dan profesi lainnya. Apakah pendengar itu heterogen artinya berbagai tingkat dan mutu pengetahuannya atau sejenisnya, dan juga perlu diperhatikan apakah ceramah yang diberikan itu hanya untuk sekali saja, menurut event atau kejadian tertentu atau untuk suatu serial yang diperlukan dalam jangka yang cukup panjang, untuk itu tentunya diperlukan

${ }^{31}$ Akhmad Sukardi, "Metode Dakwah Dalam Mengatasi Problematika Remaja", Jurnal Dakwah, Al-Munzir Vol. 9, No. 1. (2016), 22-24. 
lebih mempersiapkan dan susunan materinya. Materi dakwah paling tidak yang menjadi ukurannya adalah dapat diterima, dipahami dengan mudah oleh pendengar terhadap apa yang mubaliq sampaikan.

Di samping itu, karena pesan-pesan dakwah haruslah manusiawi yang akan membentuk pengalaman sehari-harinya nanti menurut tatanan agama, maka materi dakwah pun harus meningkat kemampuan dan akomodasi manusia dalam kehidupannya dan perkembangan kemajuannya, sesuai dengan tuntutan keperluan hidupnya. Materi dakwah haruslah memberikan relevansi antara mad'u tersebut dengan alam sekitarnya. ${ }^{32}$

Banyak sekali metode yang bisa di gunakan untuk menghadapi perilaku menyimpang pada remaja di Kelurahan Mendahara Ilir, namun berdasarkan hasil pengamatan penulis ada dua metode yang di gunakan da'i dalam berdakwah yaitu metode dakwah melalui saran kesenian, metode dakwah Bil hal dan bil lisan. Dakwah ini di lakukan oleh salah satu da'i yang bernama Habib Ali Abdullah Baroqbah.

Habib Ali Abdullah Baroqbah adalah salah satu da'i di Kelurahan Mendahara llir yang berasal dari kota jambi seberang, datang ke Kelurahan Mendahara llir setelah menerima undangan untuk mengisi pengajian di masjid al-mufakat setiap jum'at malam setelah shalat isya. Karena sering di undang oleh masyarakat Kelurahan Mendahara Ilir Habib Ali pun membuat majelis yang di beri namaLiwaul Mustofa. Beliau memberikan ceramah seperti da'i pada umumnya hanya saja sebelum beliau memulai ceramah, terlebih dahulu beliau membaca shalawat bersama masyarakat dengan di iringi permainan alat musik hadroh yang di mainkan oleh anak didiknya.

Berdasarkan observasi penulis adapun metode dakwah yang digunakan Habib Ali Abdullah Baroqbah dalam memperbaiki perilaku menyimpang pada remaja di kelurahan mendahara ilir adalah Metode dakwah bil lisan merupakan

${ }^{32}$ Ahdar, Meisil B.Wulur, Abdul Rauf Ibrahim, Publick Speaking, (Parepare : IAIN Parepare Nusantara Press, 2019), 68-75. 
dakwah yang di gunakan secara lisan atau dengan ucapan seperti ceramah, pidato tatap muka dan sebagainya untuk menyampaikan isi atau pesan dakwah, ini di lakukan oleh Ustad Ali Abdullah Baraqbah dengan membuka majelis di masjid al-mufakat di Kelurahan Mendahara Ilir, setiap jum'at malam setelah sholat isya. Berdasarkan observasi penulis ketika da'i tersebut menyampaikan dakwahnya dengan metode bil lisan da'i juga menggunakan kitab sebagai patokan dalam menyampaikan dakwahnya. Salah satu kitab yag di gunakan adalah kitab fiqih ibadah yang mana da'i menyampaikan cara berwudhu yag benar, cara sholat, berpuasa, haji dan lain sebagainya.

Metode dakwah selanjutnya melalui sarana kesenian untuk menarik pemuda-pemuda dan remaja agar bisa ikut ke dalam majelis. Banyak macam kesenian untuk dijadikan sarana media berdakwah, namun untuk Kelurahan Mendahara Ilir kesenian alat musik hadrah dan shalawatan menjadi pilihan yang tepat. Habib Ali Abdullah Baroqbah menyatakan:

Untuk membuat daya tarik kepada remaja agar hadir dalam majelis adalah dengan mengenalkan mereka alat seni hadrah, pembacaan maulid seperti sejarah nabi, berzanji, kemudian diisi dengan shalawatan-sahalawatan. Dengan adanya hadrah ini lah mereka jadi tertarik sehingga alhamdulillah sekarang sudah mulai berkembang didaerah Kelurahan Mendahara llir. Saya memilih kesenian hadrah sebagai sarana berdakwah dikarenakan hadrah ini adalah alat musik yang lebih dengan syariat islam dan untuk dibawa ke dalam masjid itu di perbolehkan. Selain itu hadrah ini juga dari dulu sudah diajarkan oleh Rasulullah SAW. ${ }^{33}$

Semua metode yang dilakukan di atas merupakan metode Ustad Ali Abdullah Baraqbah. Peran Ustad Ali sangatlah besar dalam permasalahan perilaku menyimpang remaja di Kelurahan Mendahara Ilir, bisa dikatakan beliau ujung tombak untuk melakukan perubahan kepada remaja. Beliau mulai berdakwah di kelurahan ini pada thun 2017, berawal dari permintaan masyarakat untuk mengisi pengajian di salah satu masjid yaitu al-mufakat.

${ }^{33}$ Ali Abdullah Baraqbah, Da'i Kelurahan Mendahara Ilir, Wawancara dengan Penulis, 10 April 2020, Kelurahan Mendahara Ilir, Rekaman Audio. 
Pengajian ini dilakukan setiam satu minggu satu kali tepatnya pada jum'at malam. Awalnya Ustad Ali berdakwah seperti biasanya menggunakan kitab dan ceramah. Namun setelah beberapa minggu mengisi pengajian beliau merasa ada keganjilan yang mana setiap pengajian hanya di isi dominan oleh kaum bapakbapak dan ibu-ibu, dari situlah mulai muncul pertanyaan dari ustad Ali.

Waktu terus berjalan, kemudian tiba waktu dimana masjid pengurus al mufakat mengadakan kegiatan isra mi'raj, Ustad Ali tetap menjadi penceramah dalam kegiatan ini, namun ada yang beda kali ini beliau membawa rombongan serta musik hadroh. Beliau mengajak rombongan tersebut untuk bermain hadroh tidak lain anak didik nya sendiri, sebelum melakukan ceramah Ustad Ali mengajak masarakat untuk beshalawat terlebih dahulu untuk mendapatkan syafaat dari Nabi Besar Muhammad SAW.

Adanya kegiatan isra mi'raj tadi membawa banyak remaja ke masjid ini seperti penjelasan di latar belakang bahwasanya Kelurahan Mendahara Ilir aktif dalam kegiatan hari-hari besar islam seperti isra mi'raj. Dikarenakan banyak remaja yang datang disinilah mulai pertama kali timbul rasa tertarik untuk mengikuti pengajian, terbukti dengan setelah melakukan kegiatan isra mi'raj para remaja bertanya kepada Ustad Ali bagaimana agar mereka bisa mendapatkan alat hadroh tersebut sehingga bisa terbentuk dalam satu group.

Dari pertanyaan remaja tersebut Ustad Ali mulai melakukan perannya, beliau mengarahkan remaja untuk mencari dana terlebih dahulu untuk membeli alat hadroh tersebut, setelah mendapatkan alatnya Ustad Ali mulai mengajari mereka 2 kali dalam seminggu, waktu latihan ini bisa dilakukan ketika siang hari dan malam hari sebelum pengajian di mulai. Dengan adanya latihan hadroh tadi maka para remaja mulai berdatangan untuk belajar hadroh dan langsung bisa mendengarkan siraman rohani dari Ustad Ali, sehingga seiring berjalannya waktu pintu hati mereka mulai terbuka dan sedikit demi sedikit mulai terlihat tidak melakukan perilaku menyimpang lagi. 


\section{F. Penutup}

Berdasarkan hasil penelitian yang telah dilakukan oleh penulis dilapangan, penulis menyimpulkan. Bentuk perilaku menyimpang pada remaja di kelurahan mendahara ilir berupa perilaku merokok, berjudi, minuman keras, penggunaan narkoba dan mencuri. Hal ini bisa di atasi dengan lebih memperhatikan remaja dalam pergaulan dan dalam kehidupan sehari-hari, ini termasuk peran penting bagi orang tua dalam mendidik remajanya agar tidak terjerumus kepada hal-hal yang tidak diinginkan. Di samping itu, harus ditunjang dengan berbagai upaya-upaya yaitu baiknya koordinasi yang dilakukan da'i dengan lembaga-lembaga terkait, termasuk dengan pemuka-pemuka masyarakat, pemerintah, guru dan remaja itu sendiri.

Metode dakwah yang digunakan oleh da'i adalah metode bi al lisan (ceramah dan tanya jawab) dan metode sarana media kesenian hadrah. Permasalahan perilaku menyimpang pada remaja di Kelurahan Mendahara llir bisa di selesaikan sedikit demi sedikit dengan adanya kegiatan positif serta dengan metode dakwah yang benar.

Keefektifan suatu dakwah tidak bisa diukur dari metodenya namun dari pembawaan da'i itu sendiri. Maka dapat terlihat dari pengaruh metode dakwah yang dilakukan oleh da'i tersebut. Berdakwah tidak hanya tentang ceramah ataupun khutbah, banyak metode yang bisa dilakukan untuk mengajak pada hal kebaikan salah satunya melalui permainan musik seni hadroh dan tanya jawab seputar kisah-kisah nabi Allah.

\section{DAFTAR PUSTAKA}

Al-Qur'an dan Terjemahannya, An-Nabawi Al-Qur'an Tematic Transliterasi dan Tajwid Berwarna, Bantu: Iqro Indonesia Global, 2017. Al-Qur'an dan Terjemahan. Jakarta: Pustaka An-Nahl, 2004. al-`Usairy, Ahmad, Sejarah Islam, Jakarta : Media Eka Sarana, 2003. 
Rakhmat, Jalaluddin, Islam Alternatif Ceramah-Ceramah di Kampus, Bandung: Mizan Anggota IKAPI, 1986.

Ali Aziz, Moh, Ilmu Dakwah, Jakarta: Kencana, 2004.

Halim Mahmud, Abdul, Menyingkap Rahasia-Rahasia Ibadah Dalam Islam, Jawa Barat: Keira Publishing, 2014.

Ali, Mohammad, Mohammad Asrori, Psikologi Remaja Perkembangan Peserta Didik, Jakarta: Bumi Aksara, 2004.

Ahmad Muksin, Narkoba dan Permasalahannya, Yogyakarta: Dinas Pendidikan Pemprop DIY, 2007.

Hasanudin, Hukum Dakwah, Jakarta: Pedoman Ilmu Jaya, 1996.

Munawwir , Warson, Kamus Al-Munawwir, Surabaya: Pustaka Progressif, 1994.

Natsir, M, Fungsi Dakwah Perjuangan Dalam Abdul Munir Mulkham Ideologis Gerakan Dakwah, Yogyakarta: Sipres, 1996.

M. Arif Hakim, Bahaya Narkoba Alkohol, Bandung: Cetakan Mail, 2004.

Saputra, Wahidi ,Pengantar Ilmu Dakwah, Jakarta: Rajawali Pers, 2012.

Munir, M, Metode Dakwah, Jakarta: Kencana, 2019.

Ma'aluf, Lois, Munjid fi al-Lughah wa A'lam Beirut: Dar Fikr, 1986.

Sosiologi, Tim, Sosiologi Suatu Kajian Kehidupan Masyarakat, Jakarta : Ghalia Indonesia, 2007.

Wirawan Sarwono, Sarlito, Psikologi Remaja, Jakarta: Rajawali Press, 2000.

Satori Djam'an dan Aan Komariah, Metodologi Penelitian Kualitatif, Bandung: Alfabeta, 2009.

Nazir, Metode Penelitian, Jakarta: Ghalia Indonesia, 1998.

M. Arifin, Tatang ,Menyusun Rencana Penelitian, Jakarta: Raja Grafika, 1995. untoro, Joko, Buku pintar Pelajaran SMA/MA IPS ,Jakarta: Wahyu Media, 2010. Hendryadi, Suryani ,Metode Riset Kualitatif Teori dan Aplikasi Pada Penelitian Bidang Mnajemen dan Ekonomi Islam, Jakarta: Faja Intterpratama Mandiri, 2015. 
J. Moleong, Lexy, Metodologi Penelitian Kualitatif, Bandung: Remaja Rosdakarya, 2004.

Fitrah, Luthfiyah, Metodologi Penelitian Kualitatif Tindakan Kelas dan Studi Kasus, Jawa Barat: Jejak, 2017.

Anggito, Albi, Johan Setiawan, Metodologi PenelitianKualitatif, Jawa Barat: Jejak, 2018.

Sugiono, Metodologi Penelitian Pendidikan Pendekatan Kuantitatif, Kualitatif dan $R$ dan $D$, Bandung: Alfaberta, 2008.

Ghony, Djunaidi, Fauzan Almanshur, Metode Penelitian Kualitatif, Yogyakarta: AR-Ruzz Media, 2017.

Zamadi, Farzaneh, Bersahabat Dengan Putri Anda, Jakarta : Pustaka Zahra, 2004.

Zulkifli, Psikologi Perkembangan, Bandung: Rosdakarya, 1999.

Mardani, Hukum Pidana Islam, Jakarta: Prenada Media Grop, 2019.

Geldard, Kathryn, Konseling Remaja, Yogyakarta: Pelajar, 2012.

Soedjono Dirdjosisworo, Alkoholisme Paparan Hukum dan Kriminologi, Bandung : Remadja Karya, 1984.

W. Santrock Adolescence, John, Diterjemahkan oleh Widyasinta dan Indra Sallama, Jakarta: Erlangga,2002.

Karton, Kartini, Kenakalan Remaja, Jakarta : Raja Grafindo Persada. 2014.

Jalaluddin, Psikologi Agama, Jakarta: Raja Grafindo Persada, 2003.

Ahmadi, Abu ,Psikologi Sosial, Jakarta : Rineka Cipta, 2007.

Wilis, Sofyan ,Remaja dan Masalahnya, Bandung : Alfabeta, 2012.

Mu'tadin, Pengantar Pendidikan dan Perilaku Kesehatan, Yogyakarta: Andi Offset, 2002.

AB, Syamsuddi, Pengantar Sosiologi Dakwah, Jakarta: Kharisma Putra Utama, 2016.

Yani, Ahmad, Bekal Menjadi Khatib dan Mubaliq, Jakarta : Al Qalam, 2005.

Meisil B.Wulur, Ahdar, Abdul Rauf Ibrahim, Publick Speaking, Parepare : IAIN Parepare Nusantara Press, 2019. 
Yakan, Fathi, Menuju Kepada Islam: Mengajak Umat ke Jalan Allah, terj. Chodijah Nasution, Jakarta, Bulan Bintang, 1987.

Ganda Prawira, Nanang ,Seni Rupa dan Kriya, Bandung: Sarana Tutorial Nurani Sejahtera, 2017.

Bouvier, Helene, Lebur! Seni Musik dan Pertunjukan dalam Masyrakat Madura, Jakarta: Yayasan Obor Indonesia, 2002.

Syukir, Asmuni ,Dasar-Dasar Strategi Dakwah Islam ,Surabaya: Al-Ikhlas, 1983.

Suseno Dharmo, Budi ,Lantunan Shalwat Nasyid, Yogyakarta: Media Insani, 2005.

Poerwadarminta, Kamus Besar Bahasa Indonesia, Edisi Kedua,Jakarta: Balai Pustaka, 1995.

Munir, M, Metode Dakwah , Jakarta: Kencana, 2009.

TIM Penyusun, Panduan Karya IImiah Mahasiswa Fakultas Ushuluddin IAIN STS Jambi, Jambi: Fakultas Ushuluddin IAIN STS Jambi, 2016.

Pusat Pembinaan dan Pengembangan Bahasa, Kamus Besar Bahasa Indonesia, Jakarta: Balai Pustaka, 1998.

Jamel, Anggota Grop Hadrah Liwaul Mustofa Wanwancara dengan Penulis. 7 April 2020. Kelurahan Mendahara Ilir. Rekaman Audio.

M.Jafri, Tokoh Adat Wawancara dengan Penulis. 23 Februari 2020. Kelurahan Mendahara. Rekaman Audio

Saleh, Lurah mendahara Ilir Wawancara dengan Penulis. 22 Februari 2020. Kelurahan Mendahara Ilir. Dokumen.

Yahya, Salah Satu Da'i di Kelurahan Mendahara Ilir Wawancara dengan Penulis. 22 Februari 2020. Kelurahan Mendahara Ilir. Rekaman Audio.

Muhammad Nuur, Kanit Intelkom Polsek Mendahara Wawancara dengan Penulis. 23 Februari 2020. Kelurahan Mendahara Ilir. Rekaman Audio.

Abdul Thalib, Kelompok Penyuluh Agama Islam Mendahara Wawancara dengan Penulis. 20 Februari 2020. Kelurahan Mendahara Ilir. Rekaman Audio. 
Abdul Asis, Remaja Anggota Tim Hadroh Liwa'ul Mustofa Mendahara Ilir Wawancara dengan Penulis. 24 Februari 2020. Kelurahan Mendahara Ilir. Rekaman Audio.

Ahmad Masyuri, Remaja Angota Tim hadroh Liwa'ul Mustofa Wawancara dengan Penulis. 22 Februari 2020. Kelurahan Mendahara Ilir. Rekaman Audio.

Ruslan, Informan Remaja Pengguna Minuman Keras Wawancara dengan Penulis, 2 April 2020. Kelurahan Medahara llir. Rekaman Audio.

Reza Gunawan, Informan Remaja Pengguna Rokok Wawancara dengan Penulis. 2 April 2020. Kelurahan Mendahara Ilir. Rekaman Audio.

Rudi, Pemuda Ketua Karang Taruna Kelurahan Mendahara Ilir Wawancara dengan Penulis. 22 Februari 2020. Kelurahan Mendahara Ilir. Rekaman Audio

Yuriko, Kanit Pembinaan Masyarakat Polsek Kelurahan Mendahara Ilir Wawancara dengan Penulis. 23 Februari 2020. Kelurahan Mendahara Ilir. Rekaman Audio.

Ali Abdullah Baraqbah, Da'i Kelurahan Mendahara Ilir Wawancara dengan Penulis. 10 April 2020. Kelurahan Mendahara Ilir. Rekaman Audio.

Wahyu Saputra, Remaja Aktif Mengikuti Majelis Taklim Wawancara dengan Penulis. 6 April 2020. Kelurahan Mendahara Ilir. Rekaman Audio.

Reza Pajarismanda, Remaja Berperilaku MenyimpangWawancara dengan Penulis. 8 April 2020. Kelurahan Mendahara Ilir. Rekaman Audio.

Bagas Renaldi, Remaja Perokok AktifWawancara dengan Penulis. 7 April 2020. Kelurahan Mendahara Ilir. Rekaman Audio.

Andri Sulaiman, Remaja Aktif Mengikuti Kegiatan Majelis Taklim Wawancara dengan Penulis. 7 April 2020. Kelurahan Mendahara Ilir. Rekaman Audio.

Yoga Pratama, Remaja Kurang Perhatian Orang Tua Wawancara dengan Penulis. 6 April 2020. Kelurahan Mendahara Ilir. Rekaman Audio.

Septi Nugroho, Rizky ,"Perilaku Merokok Remaja”, Jurnal (2010), 16. 
Akhmad Sukardi, "Metode Dakwah Dalam Mengatasi Problematika Remaja", Jurnal Dakwah, Al-Munzir Vol. 9, No. 1. (2016), 22-24.

Nurbini, Bahasa Dakwah Untuk Kalangan Remaja Terpelajar, Jurnal dakwah, XI, No.1 (2011), 122-123.

Jimmy Simangunsong, "Penyalagunaan Narkoba Di Kalangan Remaja", E-Jurnal, (2015), 13.

Misbakhul Munir, "Pengetahuan dan Sikap Remaja Tentang Resiko Merokok Pada Santri Mahasiswa di Asrama UIN Sunan Ampel Surabaya", KLOROFIL Vol. 1 No. 2, (2018), 93-104. 